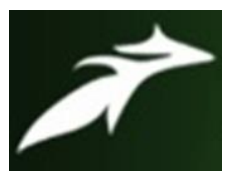

Naveena Kudikala et al, International Journal of Advances in Agricultural Science \& Technology,

Vol.8 Issue.10, October-2021, pg. 74-83

ISSN: $2348-1358$

Impact Factor: 6.057

NAAS Rating: 3.77

\title{
Impact of KVK Trainings on Economic Condition of Vegetable Growers in Prayagraj District of Uttar Pradesh
}

\author{
Naveena Kudikala*; Dr. Syed H Mazhar**; Dr. Dipak Kumar Bose**** \\ *Msc (Agriculture), Department of Agricultural Extension \& Communication, SHUATS, Prayagraj \\ **Associate Professor, Department of Agricultural Extension \& Communication, SHUATS, Prayagraj \\ ***Associate Professor, Department of Agricultural Extension \& Communication, SHUATS, Prayagraj \\ DOI: 10.47856/ijaast.2021.v08i10.009
}

\begin{abstract}
:
The present investigation was conducted in chaka, jasra, and kaundhiara blocks of Prayagraj district, Uttar Pradesh. One hundred twenty respondents were selected randomly from 10 villages which were selected from the data given by KVK staff of naini, prayagraj. Respondents were taken as trainees and non-trainees to compare the economic condition between them. Where non trainees were selected from 5 of the 10 villages for appropriate results.

The primary data were gathered by the researcher itself through pre-structured interview schedule. Appropriate statistical tools were used to interpret the collected data to draw logical conclusion. The finding inferred that majority of trainees have shown medium and high level of economical status, whereas non trainees have shown low level of economical status when annual income, physical assets, land holding were taken as a parameters to compare.
\end{abstract}

Keywords: Impact, KVK trainings, Economic

\section{INTRODUCTION:}

India is the second largest producer of vegetables in the world (surpassed only by China), accounting for about 10 per cent of the world's production. In 2002, India produced 78.2 million tons from 5.73 million ha of land. Indian farmers grow an amazing number that is 175 different vegetables but potato, tomato, onion, cabbage and cauliflower account for 60 per cent of total production. It is projected that the domestic vegetable requirements will rise from current levels of 83- 91 million tons to 151-193 million tons by 2030. Indian farmers today cannot meet the 


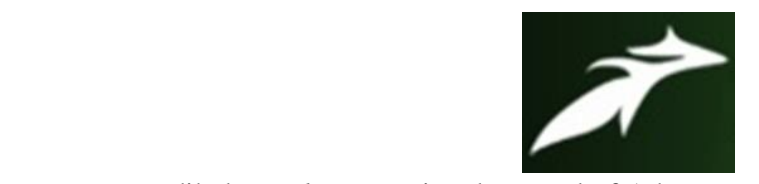

Naveena Kudikala et al, International Journal of Advances in Agricultural Science \& Technology,

Vol.8 Issue.10, October-2021, pg. 74-83

ISSN: 2348-1358

Impact Factor: 6.057

NAAS Rating: 3.77

high domestic demand for vegetables, as India imports approximately \$678 million of vegetables annually.

To increase domestic vegetable production, improvements are first needed in the vegetable seed industry. There are now more than 50 seed companies developing new vegetable varieties, with increased emphasis on high-yielding hybrids. The Indian Council of Agricultural Research has three major institutes for conducting research on vegetables: Indian Institute of Horticultural Research (IIHR) in Bangalore, Indian Institute for Vegetable Research (IIVR) at Varanasi, and Indian Agriculture Research Institute (IARI) in New Delhi. Almost all agricultural universities and the State Department of Agriculture along with the KVK are involved in vegetable research and development. Among the 25,000 plant scientists in India, at least 1,000 are conducting research on vegetables. To increase year-round vegetable consumption, the seasonality of production must be reduced. Processing can make vegetables more accessible year-round, but less than 7 per cent of India's vegetable production is processed.

Analysis of impact refers to the outcome of the results of activities and net effect of activities done by KVK training on economic condition of the farmers. Since ancient time more emphasize has been laid of the training as it is one of the integral components of development programme. Krishi Vigyan Kendra (KVK) are agricultural extension centers created by ICAR (Indian Council for Agricultural Research) and its affiliated institutions at district level to provide various types of farm support to the agricultural sector. The first KVK was established during 1974 (Pondicherry) and has grown as a largest network in the country. KVK provide several farm support activities like providing technology dissemination to farmers, training, awareness etc. To achieve the set objectives KVKs undertake following types of activities in the adopted villages: (1) Farm Advisory Service (2) Training programme for different categories of people. (3) Training programme for the extension functionaries. (4) Front Line Demonstration (Fill) (5) On Farm Testing (OFT). They play a vital role in conducting on farm testing to demonstrate location specific agricultural technologies. KVK conducts demonstrations to prove the potential of various crops at farmers' fields. They also conduct need based training 


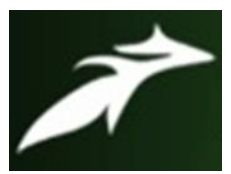

Naveena Kudikala et al, International Journal of Advances in Agricultural Science \& Technology,

Vol.8 Issue.10, October-2021, pg. 74-83

ISSN: $2348-1358$

Impact Factor: 6.057

NAAS Rating: 3.77

programme for the benefit of farmers and farm women, rural youths. KVK are creating awareness about improved agricultural technologies through large number of extension programme.

\section{RESEARCH METHODOLOGY:}

The present study was purposively undertaken in Jasra, Chaka and Kaundhiara blocks of Prayagraj district in Uttar Pradesh. Ten villages were purposively selected on the basis of Data given by the KVK staff of naini, prayagraj, where respondents were taken as trainees and non trainees. From each selected village, trainees and non trainees were selected making a sample of 120 respondents. Pretested interview schedule was used for collection of data. The collected data were classified, tabulated and analyzed in the light of the objectives.

Ex-post- facto research design was followed and the variables were measured by using suitable scale and procedure adopted by various researchers in past with few modification. Appropriate statistical tools were used to draw the inferences.

\section{RESULTS AND DISCUSSION:}

Socio-economical characteristics of respondents

The socio-economic characteristics of the respondents were studied and the data are given below.

Table 1:- Socio-economic characteristics wise distribution of the respondents $(\mathrm{N}=120)$

\begin{tabular}{|c|c|c|}
\hline 1.AGE & TRAINEE & NONTRAINEE \\
\hline YOUNG & $\mathrm{F}=7, \mathrm{P}=11.67 \%$ & $F=7, P=11.67 \%$ \\
\hline MIDDLE & $\mathrm{F}=32, \mathrm{P}=56.7 \%$ & $F=13, P=21.67 \%$ \\
\hline OLD & $F=21, P=36.66$ & $F=40, P=66.66$ \\
\hline 2.EDUCATION & TRAINEE & NONTRAINEE \\
\hline LOW & $\mathrm{F}=10, \mathrm{P}=16.66 \%$ & $\mathrm{~F}=25 \mathrm{P}=41.66 \%$ \\
\hline MEDIUM & $\mathrm{F}=30, \mathrm{P}=50 \%$ & $\mathrm{~F}=20, \mathrm{P}=33.33 \%$ \\
\hline HIGH & $\mathrm{F}=20 \mathrm{P}=33.33 \%$ & $F=15, P=25 \%$ \\
\hline
\end{tabular}




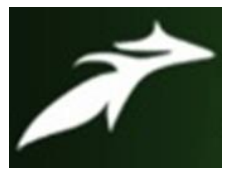

Naveena Kudikala et al, International Journal of Advances in Agricultural Science \& Technology,

Vol.8 Issue.10, October-2021, pg. 74-83

ISSN: 2348-1358 Impact Factor: 6.057 NAAS Rating: 3.77

\begin{tabular}{|c|c|c|}
\hline 3.EXTENSION CONTACT & TRAINEE & NONTRAINEE \\
\hline LOW & $F=6, P=10 \%$ & $\mathrm{~F}=34, \mathrm{P}=56.33 \%$ \\
\hline MEDIUM & $F=41, P=68.33 \%$ & $\mathrm{~F}=23, \mathrm{P}=38.33 \%$ \\
\hline HIGH & $F=13, P=21.67 \%$ & $\mathrm{~F}=3, \mathrm{P}=5 \%$ \\
\hline 4.SOCIALPARTICIPATION & TRAINEE & NONTRAINEE \\
\hline LOW & $F=8, P=13.34 \%$ & $F=24, P=40 \%$ \\
\hline MEDIUM & $\mathrm{F}=26, \mathrm{P}=43.33 \%$ & $F=18, P=30 \%$ \\
\hline HIGH & $F=26, P=43.33 \%$ & $F=18, P=30 \%$ \\
\hline 5.MASSMEDIA EXPOSURE & TRAINEE & NONTRAINEE \\
\hline LOW & $F=6, P=10 \%$ & $\mathrm{~F}=7, \mathrm{P}=11.75 \%$ \\
\hline MEDIUM & $F=12, P=20 \%$ & $\mathrm{~F}=22, \mathrm{P}=36.67 \%$ \\
\hline HIGH & $F=42, P=70 \%$ & $\mathrm{~F}=31, \mathrm{P}=51.66 \%$ \\
\hline 6.LAND HOLDING & TAINEE & NONTRAINEE \\
\hline LOW & $\mathrm{F}=22, \mathrm{P}=36.67 \%$ & $\mathrm{~F}=31, \mathrm{P}=51.66 \%$ \\
\hline MEDIUM & $\mathrm{F}=26, \mathrm{P}=43.44 \%$ & $\mathrm{~F}=20, \mathrm{P}=33.33 \%$ \\
\hline HIGH & $F=12, P=20.00 \%$ & $F=9, P=15 \%$ \\
\hline 7.PHYSICAL ASSETS & TRAINEE & NONTRAINEE \\
\hline LOW & $\mathrm{F}=13, \mathrm{P}=21.66 \%$ & $\mathrm{~F}=38, \mathrm{P}=63.33 \%$ \\
\hline MEDIUM & $F=40, P=66.66 \%$ & $\mathrm{~F}=20, \mathrm{P}=33.33 \%$ \\
\hline HIGH & $F=7, P=11.66 \%$ & $F=2, P=3.33 \%$ \\
\hline 8.ANNUAL INCOME & TRAINNE & NONTRAINEE \\
\hline LOW & $F=21, P=35 \%$ & $F=41, P=68.6 \%$ \\
\hline MEDIUM & $F=28, P=46.7 \%$ & $F=12 P=20 \%$ \\
\hline HIGH & $F=11, P=187 \%$ & $F=7, P=11.7 \%$ \\
\hline
\end{tabular}

F =FREQUENCY, P= PERCENTAGE 


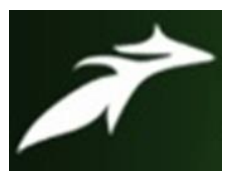

Naveena Kudikala et al, International Journal of Advances in Agricultural Science \& Technology,

Vol.8 Issue.10, October-2021, pg. 74-83

ISSN: $2348-1358$

Impact Factor: 6.057

NAAS Rating: 3.77

Table-1.Shows that majority, of the trainees were of middle age (56.66) and non trainees were of old age (66.66), majority of the trainees have shown high level of education, non trainees have shown medium level of education. when it comes to extension contact trainees have shown medium level (68\%), non trainees have shown (56\% low level), also trainees have shown medium level in social participation but, non trainees have shown low level of social participation, coming to the economic status of the trainees they have show medium level in income, land holding and assets, but non trainees have shown low level of these parameters. Hereby, I conclude that there is an impact of KVK trainings on economic condition of the vegetable growers in prayagraj district of Uttar Pradesh.

Table 2:- Knowledge of Respondents Regarding KVK Trainings on Vegetable Production

\begin{tabular}{|c|c|c|}
\hline KNOWLEDGE & TRAINEE & NON TRAINEE \\
\hline $\begin{array}{c}\text { 1.INTEGRATED PEST MANAGEMENT IN } \\
\text { CUCUMBER }\end{array}$ & $\mathrm{F}=52, \mathrm{P}=86.66$ & $F=12, P=20$ \\
\hline 2.MUSHROOM CULTIVATION & $F=39, P=65$ & $\mathbf{F}=\mathbf{0 , P}=\mathbf{0}$ \\
\hline 3.INTERCROPPING OF VEGETABLE & $F=45, P=75$ & $F=13, P=21.66$ \\
\hline $\begin{array}{c}\text { 4.SCIENTIFIC PRODUCTION TECHNOLOGY } \\
\text { OF ONION }\end{array}$ & $F=35, P=65$ & $\mathbf{F}=\mathbf{0 ,} \mathbf{P}=\mathbf{0}$ \\
\hline 5.SOLAR WATER PUMP & $F=39, P=65$ & $F=3, P=5$ \\
\hline 6.ORGANIC FARMING IN VEGETABLES & $F=36, P=60$ & $F=10, P=16.66$ \\
\hline 7.TOMATO NEW VARIETIES PRODUCTION & $\mathrm{F}=56, \mathrm{P}=93.33$ & $\mathrm{~F}=5, \mathrm{P}=8.33$ \\
\hline 8.INTEGRATED FARMING SYSTEM & $F=45, P=75$ & $F=35, P=65$ \\
\hline
\end{tabular}

\begin{tabular}{|c|c|c|}
\hline KNOWLEDGE & TRAINEE & NON TRAINEE \\
\hline LOW & $F=7, P=11.66$ & $\mathrm{~F}=35, \mathrm{P}=58.33$ \\
\hline MEDIUM & $\mathrm{F}=38, \mathrm{P}=63.33$ & $F=21, P=35$ \\
\hline HIGH & $F=15, P=25.0$ & $F=4, P=6.66$ \\
\hline
\end{tabular}




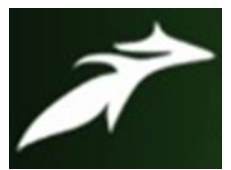

Naveena Kudikala et al, International Journal of Advances in Agricultural Science \& Technology,

Vol.8 Issue.10, October-2021, pg. 74-83

ISSN: $2348-1358$

Impact Factor: 6.057

NAAS Rating: 3.77

Table 3:-Impact of KVK Trainings on Economic Condition of Vegetable Growers

\begin{tabular}{|c|c|c|}
\hline $\begin{array}{c}\text { IMPACT OF KVK } \\
\text { TRAININGS(PARAMETE } \\
\text { RS) }\end{array}$ & TRAINEE & NON TRAINEE \\
\hline 1.HIGH YEILD & $F=45, P=75$ & $F=14, P=23.33$ \\
\hline 2.LESS PEST ATTACK & $\begin{array}{c}\mathrm{F}=32, \mathrm{P}=58.3 \\
3\end{array}$ & $\mathrm{~F}=22, \mathrm{P}=36.33$ \\
\hline $\begin{array}{l}\text { 3.VALUE ADDED } \\
\text { PRODUCTS }\end{array}$ & $\begin{array}{c}\mathrm{F}=35, \mathrm{P}=58.3 \\
3\end{array}$ & $F=25, P=41.66$ \\
\hline $\begin{array}{l}\text { 4.IMPROVEMENT IN } \\
\text { QUALITY OF CROPS }\end{array}$ & $\begin{array}{c}\mathrm{F}=38, \mathrm{P}=63.3 \\
3\end{array}$ & $F=26, P=43.33$ \\
\hline 5.WATER AVAILABILITY & $\begin{array}{c}\mathrm{F}=56, \mathrm{P}=93.3 \\
3\end{array}$ & $F=40, P=66.66$ \\
\hline $\begin{array}{c}\text { 6.USAGE OF ORGANIC } \\
\text { WASTE }\end{array}$ & $\begin{array}{c}F=40, P=66.6 \\
6\end{array}$ & $\mathrm{~F}=35, \mathrm{P}=58.33$ \\
\hline $\begin{array}{c}\text { 7.PRODUCTION OF } \\
\text { MUSHROOMS }\end{array}$ & $F=39, P=65$ & $\mathbf{F}=\mathbf{0}, \mathbf{P}=\mathbf{0}$ \\
\hline $\begin{array}{c}\text { 8.INCREASE IN } \\
\text { PRODUCTION OF } \\
\text { VAGETABLES }\end{array}$ & $F=39, P=65$ & $F=25, P=41.66$ \\
\hline $\begin{array}{c}\text { 9.SPACE UTILIZATION } \\
\text { THROUGH } \\
\text { INTERCROPPING }\end{array}$ & $F=45, P=75$ & $F=13, P=21.66$ \\
\hline
\end{tabular}

\begin{tabular}{|l|c|c|}
\hline CATEGORY & TRAINEE & NON TRAINEE \\
\hline LOW & F=8,P=13.33 & F=15,P=35 \\
\hline MEDIUM & F=35,P=58.33 & F=30,P=50 \\
\hline HIGH & F=17,P=28.33 & F=15,P=35 \\
\hline
\end{tabular}




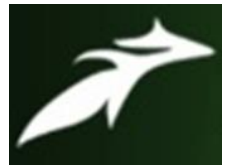

Naveena Kudikala et al, International Journal of Advances in Agricultural Science \& Technology,

Vol.8 Issue.10, October-2021, pg. 74-83

ISSN: 2348-1358

Impact Factor: 6.057

NAAS Rating: 3.77

Table 4:-Regression Coefficient of the Independent Variables with the Knowledge of Trained Vegetable Growers

\begin{tabular}{|c|c|c|c|}
\hline $\begin{array}{r}\text { INDEPENDENT } \\
\text { VARIABLES }\end{array}$ & $\begin{array}{l}\text { REGRESSION } \\
\text { COEFFICIENT }\end{array}$ & $\begin{array}{l}\text { STANDAR } \\
\text { D ERROR }\end{array}$ & T-TEST \\
\hline$\overline{\text { AGE }}$ & 1.2102 & 0.4303 & $2.8127 \mathrm{NS}$ \\
\hline EDUCATION & 1.1986 & 0.2175 & $5.5111 \mathrm{~S}$ \\
\hline INCOME & 1.2055 & 1.4473 & $10.8329 \mathrm{~S}$ \\
\hline LAND & 1.1731 & 1.8986 & $6.6179 \mathrm{~S}$ \\
\hline $\begin{array}{c}\text { PHYSICAL } \\
\text { ASSETS }\end{array}$ & 0.8350 & 0.3756 & $7.2232 \mathrm{~S}$ \\
\hline $\begin{array}{c}\text { SOCIAL } \\
\text { PARTICIPATION }\end{array}$ & 1.0833 & 1.1066 & $0.9790 \mathrm{NS}$ \\
\hline $\begin{array}{c}\text { MEDIA } \\
\text { EXPOSURE }\end{array}$ & -0.0968 & 0.8288 & $\begin{array}{c}- \\
0.1168 N S\end{array}$ \\
\hline $\begin{array}{c}\text { EXTENSION } \\
\text { CONTACT }\end{array}$ & 0.8673 & $\mathbf{0 . 0 5 3 0}$ & $16.3583 \mathrm{~S}$ \\
\hline
\end{tabular}

*NS= NON SIGNIFICANT, S=SIGNIFICANT 


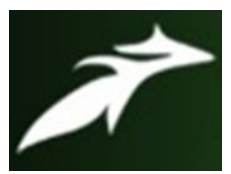

Naveena Kudikala et al, International Journal of Advances in Agricultural Science \& Technology,

Vol.8 Issue.10, October-2021, pg. 74-83

ISSN: $2348-1358$

Impact Factor: 6.057

NAAS Rating: 3.77

Table 4.1:- Regression Coefficient of the Independent Variables with the Knowledge of Un Trained Vegetable Growers

\begin{tabular}{|c|c|c|c|}
\hline $\begin{array}{c}\text { INDEPENDENT } \\
\text { VARIABLES }\end{array}$ & $\begin{array}{l}\text { REGRESSION } \\
\text { COEFFICIENT }\end{array}$ & $\begin{array}{c}\text { STANDARD } \\
\text { ERROR }\end{array}$ & T-TEST \\
\hline AGE & $\begin{array}{c}- \\
0.8447\end{array}$ & 0.2578 & $-3.2158 \mathrm{NS}$ \\
\hline EDUCATION & 3.1000 & 0.1732 & $17.8979 \mathrm{~S}$ \\
\hline INCOME & 0.7641 & 0.3623 & $12.1088 \mathrm{~S}$ \\
\hline LAND & 1.4091 & 0.0787 & 17.8979 S \\
\hline $\begin{array}{c}\text { PHYSICAL } \\
\text { ASSETS }\end{array}$ & 0.8611 & 0.0481 & 17.8979 S \\
\hline $\begin{array}{c}\text { SOCIAL } \\
\text { PARTICIPATION }\end{array}$ & 3.7500 & 2.4537 & $1.5283 \mathrm{NS}$ \\
\hline $\begin{array}{c}\text { MEDIA } \\
\text { EXPOSURE }\end{array}$ & $\begin{array}{c}- \\
1.2551\end{array}$ & 0.2533 & $-4.9545 \mathrm{NS}$ \\
\hline $\begin{array}{c}\text { EXTENSION } \\
\text { CONTACT }\end{array}$ & 0.9818 & 0.1087 & $9.0327 \mathrm{~S}$ \\
\hline
\end{tabular}

From table no: 4 \& 4.1; we observed that, in table.4.Education, Land, Income and Physical assets, Extension contact are significant with the knowledge of trained respondents in KVK training. Because increase in level of education increases the ability to receive the knowledge, Whereas, increase in land holding increases the adoption of knowledge to gain, more income, also greater the income ,greater the ability to receive the knowledge .Likewise, increase in extension contact increases the ability to receive more knowledge. Also, Age, Social participation, Media exposure are not significant with knowledge in KVK training.Table.4.1, Age and Extension contact are significant with the knowledge in KVK training. Increase in age and Extension contact had led respondents to receive knowledge ,also Education, Income, Land, Physical assets, Media exposure and Social participation are non significant with the knowledge in KVK training. since lack of education didn't support untrained farmers to receive enough knowledge, decrease in land, income and physical assets ,social participation and less exposure to mass media has led untrained farmers lack in enough knowledge. 


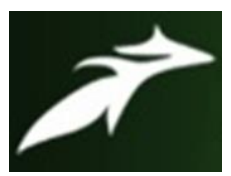

Naveena Kudikala et al, International Journal of Advances in Agricultural Science \& Technology,

Vol.8 Issue.10, October-2021, pg. 74-83

ISSN: $2348-1358$

Impact Factor: 6.057

NAAS Rating: 3.77

Table 5:- Regression Coefficient of the Independent Variables with the Impact of Trained Vegetable Growers

\begin{tabular}{|c|c|c|c|}
\hline $\begin{array}{c}\text { INDEPENDENT } \\
\text { VARIABLES }\end{array}$ & $\begin{array}{c}\text { REGRESSION } \\
\text { COEFFICIENT }\end{array}$ & STANDARD ERROR & T- TEST \\
\hline AGE & 1.0605 & 0.2813 & $3.7698 \mathrm{~S}$ \\
\hline EDUCATION & 1.3500 & 0.2598 & $5.1962 \mathrm{~S}$ \\
\hline INCOME & 0.9247 & 1.3168 & $11.7022 \mathrm{~S}$ \\
\hline LAND & 0.8654 & 1.6987 & $4.5094 \mathrm{~S}$ \\
\hline PHYSICAL ASSETS & 0.6845 & 0.3784 & $12.809 \mathrm{~S}$ \\
\hline $\begin{array}{c}\text { SOCIAL } \\
\text { PARTICIPATION }\end{array}$ & 1.0000 & 0.8660 & $1.1547 \mathrm{NS}$ \\
\hline MEDIA EXPOSURE & -0.024 & 0.7124 & -0.0340 NS \\
\hline $\begin{array}{c}\text { EXTENSION } \\
\text { CONTACT }\end{array}$ & 0.7347 & 0.1060 & $6.9282 \mathrm{~S}$ \\
\hline
\end{tabular}

From Table.5 \& 5.1: Age, Education, Land, Income, Physical assets, Extension contact are significant with the impact by KVK training. Because, effective training knowledge received by trained farmers led to show impact whereas, Social participation and Media exposure are non significant with the impact by KVK training. Table no.5.1 .Age, Education, Income, Land, Physical assets, Media exposure, Extension contact, Social participation are non significant with the impact by KVK training. Since compared to trained farmers untrained farmers are lacking in all the aspects that led negatively significant in impact of KVK training.

\section{CONCLUSION:}

The findings of the study can be understood that, economic status of the trainees and non trainees has shown a difference in terms of physical assets, annual income, land holding. Trainees have high and medium level of land holdings, physical assets and annual income; non trainees have low level of income, land and assets. this aspect of study also suggested the social profile of the respondents, who got training are mostly of middle age ,and studied up to primary school, have more social participation, extension contact and media exposure .Hence it is concluded that, there is an impact of KVK training on economic condition of the vegetable growers. 


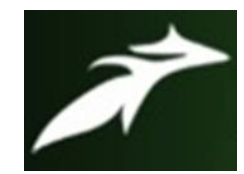

Naveena Kudikala et al, International Journal of Advances in Agricultural Science \& Technology,

Vol.8 Issue.10, October-2021, pg. 74-83

ISSN: $2348-1358$

Impact Factor: 6.057

NAAS Rating: 3.77

\section{REFERENCES}

[1]. Mariano,Jhon (2013) We employ binary log it and Poisson estimators to model socioeconomic, institutional and environmental factors influencing the adoption of certified seeds, in particular, and integrated crop management practices, in general, in vegetables production in the Philippines.

[2]. Gautam, VM.Vijay Sharma, (2014) the study was conducted in Haidergarh block of Barabanki district to study the impact of trainings provided by KVK. 50 trained respondents were selected randomly from KVK and 50 untrained respondents were selected randomly from one uncovered village keeping in view of similar attributes.

[3]. Hatia(2016). Organic agriculture is an opportunity for sustainable agricultural development but some farmers are reluctant to convert because of the constraints/problems they face in its adoption. Keeping above in view, the research was conducted in the purposively selected three districts of Haryana viz., Kaithal, Karnal and Kurukshetra, because of the maximum area as well as production of vegetables.

[4]. Singh (2017) The socio-economic profile including age, gender, educational qualification, landholdings, social participation, number of dependents, number of training attended, were found to be significantly associated with the level of knowledge of the KVK contact farmers.

[5]. Tengli (2019). Adoption is a mental process of an individual; it is a decision of full use of an innovation as the best course of action available. The aforementioned study was conducted in Navsari and Surat districts of South Gujarat during the year 2014-2016. The primary data was collected from 100 respondents by following personal interview method and using structured interview schedule

[6. Shetty. (2020). vegetables are the nutritious food crops India. The present study was undertaken to investigate the use of agricultural information sources and services by farmers for improving the productivity of vegetable crops in the Bishnupur district of Manipur. From each village 20 farmers were randomly selected making a sample size of 80 respondents were found positive and highly significant when correlated with the utilization pattern. 